\title{
A DIARY OF PRISON LIFE IN SOUTHERN PRISONS
}

\author{
by Amos W. Ames \\ Company " $H$ " \\ Fourth lowa Infantry
}

The Fourth Regiment Iowa Volunteer Infantry was formed in the fall of 1861. It participated in many battles inincluding those of Pea Ridge, Chickasaw Bayou and Kenesaw Mountain. Of the 1,557 soldiers of the Fourth Infantry, 49 were captured. Amos Washington Ames was one of the 49.

Amos W. Ames was born Feb. 22, 1840 in Era, Penn., to Cyrenus and Martha Ames. In 1855 the family moved to Afton, Iowa and began farming near Three Mile Creek. Ames served as a corporal in the Fourth Infantry from 1861 to 1863. He re-enlisted Jan. 25, 1864. Seven months later he was taken prisoner at Jonesboro, Ga. The following account was kept by Ames while he was a prisoner-of-war in several Confederate compounds.

The original dairy has been donated to the State Department of History and Archives by Ames' grandson, Amos $M$. Ames of Baxter, Iowa.

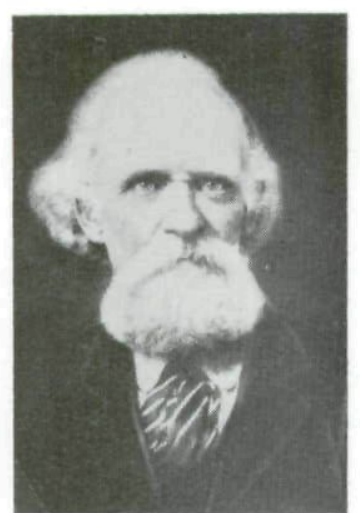

Amos W. Ames

Aug. 31, 1864. [Gen. William T.] Sherman's army is in position at Jonesboro [Ga.], 23 miles in the rear of Atlanta [Ga.]. We reached here last night. [Lt. Gen. William J.] Hardees corps confronts us. It is intrenching along the railroad. Companies "I" and " $\mathrm{H}$ " are supporting a section of artillery, 200 yards in advance of our works, which is shelling Jonesboro. About 2 o'clock, P.M., the rebels charge our position and are repulsed. After the fighting is ended am sent out with ten or twelve men from company " $\mathrm{H}$ " to act as skirmishers. I halt my men, and go ahead to reconnoiter, and am captured. Taken to Jonesboro, and placed under guard with other prisoners. 
Sept. 1, Rebels gave us a little corm bread and musty bacon, which was contributed by the soldiers. Turned over to the provost marshal and confined in a garret, closely guarded. Afternoon sent to Griffin [Ga.].

2, At 9 o'clock, A.M., started for Andersonville [Ga.] on top of freight cars, 23 prisoners besides myself. 25 miles below had a collission [sic] with a North bound train, 44 rebels Killed and wounded. One prisoner broke his leg, another sprained his ankle jumping off. I make my escape. Travel hard all day and until after dark, then after marking my course, by bending down a bush, lay down in swamp to sleep.

3, Traveled on through forests, swamps, and quagmires, and shunning all roads. Was very tired and worn out. Towards evening was within fifteen miles of Lovejoy [Ga.] and could hear cannonading. Half an hour afterward was recaptured by scout from 3d Ark. (rebel) cavalry.

4, Under guard all day with rebel wagon train.

5, Sent to Griffin, and placed in my former quarters, where I find two of my comrades that left the train after me, and had been retaken with hounds.

6, Under guard all day in guard house at Griffin. Get very little to eat.

7, Sent to Macon [Ga.], and put in stockade. Drew one days rations - a pint of unsifted meal and four ounces bacon to a man.

8, Still at Macon. Drew two days rations of meal, bacon, etc.

9 , Still at Macon. Weather warm. Some federal prisoners brought in.

10, Weather cooler. Assisted in removing federal wounded from hospital to the cars

11, Today is Sunday, Had preaching at 1 o'clock, P.M., by rebel preacher, about Daniel in the lion's den; Thought it very appropriate. Some of [Brig. Gen. Hugh J.] Kilpatrick's men brought in Drew one day's ration of meal and molasses. Preaching in the evening Did not attend.

12, Deserter from 78th N.Y., bucked and gagged for having stolen bottle of molasses from rebel prisoners. There are quite a number of rebel prisoners confined here with us. Some of them are deserters; Some are held for crime and others 
are awaiting to be sent to the front. Night quite cold and I have no blanket. Could not sleep any

13, Six or Seven of Kilpatrick's men brought in - were taken near Eastpoint [East Point, Ga.]. Rumors afloat that Sherman and [Gen. John B.] Hood have agreed to exchange prisoners taken on the Atlanta Campaign.

14, Rumors that difficulties about an exchange of prisoners have been removed, and that soon there will be a general exchange.

15, Some escaped federal prisoners brought in.

16, I feel a little unwell today. Tunnel discovered. Two federal prisoners arrested. Drunken rebel captain brought in. Rebel prisoners rob him of $\$ 360$, and another rebel officer of $\$ 4,700$, so it is reported.

17, A search is made for the money-It cannot be found. The two men, caught tunneling, are shackled with ball and chain. Rainy night.

18, Rainy morning. Two federal prisoners fight. Rains during the night.

19, Rainy morning. Four escaped prisoners brought in, Rumors that Sherman's men will soon be exchanged, and that the truce has been extended ten days longer.

20, Cloudy morning and rainy. Another drunken rebel brought in and the rebel prisoners rob him as usual. The rebs occupy one side of the stockade. We the other.

21, Cooler. Five escaped federal prisoners brought in. Rains in the afternoon. Are told that we are to leave Macon, tomorrow. If we do I shall 20.18.25.-20.15.-5.19.3.1.16.5. (try to escape )

22, Cool and cloudy. 100 federal prisoners who had been taken to Rough and Ready, near Atlanta, for exchange, and for some cause refused, brought in Oh the horrors of war! that liberty almost within their grasp should thus be snatched from them. After dark rebel prisoner shot in trying to escape. Note-After the fall of Atlanta, an arrangement was made between Sherman, and Hood, for an exchange of prisoners taken on the Atlanta Campaign. The confederates acted in bad faith. They picked out those whose term of enlistment had expired; and others who were unfit for service, and for this reason they were refused by our authorities. 
23, Two federal prisoners escaped during last night. Lamps are put up around the stockade. At 10 o'clock A.M., the 100 that came in last night, start for Savannah [Ga.] 260 more brought in from Rough And Ready having failed to get exchanged.

24, Rainy. The 260 leave at 4 o'clock P.M. 278 come in the front.

25, Weather cooler. Prisoners leave at 3 o'clock P.M.

26, Ninety prisoners brought in from the front. 190 officers come in from Charleston, S.C. 140 are taken to Rough And Ready for exchange.

27, Several deserters, and drunken rebels, brought in. Negro barber comes into the prison to practice his barberous profession.

28, A few federal prisoners brought in. The officers and some of the men taken out on parole of honor.

29, A partition being made in the stockade to separate reb. from federal prisoners.

30 , One month a prisoner. Rebel prisoner chops his hand nearly off with foot adz to keep from being sent to the front. 77 rebel prisoners leave for the front.

Oct. 1, Day cool and cloudy with rain.

2, Weather warm. Six or Seven federal prisoners brought in. Night dark and rainy. Two federal prisoners try to escape. They are discovered by the guard and fired at. Strict orders not to leave our quarters or would be fired upon.

3, Cool morning. Early roll call. "All present and accounted for". A rainy day.

4, Cool and breezy

5 , Seventeen federal prisoners brought in

6, Forenoon cool and pleasant. Afternoon rainy. Two Federal and several rebel prisoners brought in Rumors of leaving soon for another prison

7, Two escaped federal prisoners brought in. Night quite cold and windy. No blanket.

8 , Cold and windy. A few prisoners are brought in. Night very cold-could not sleep

9, The sun shines brightly but it is cold and windy. Night very cold with frost. Sat up all night. 
Note: When I was captured I had neither knapsack nor blanket and none was furnished by the rebels. A prisoner, who had a blanket, would pair off with another who was equally well provided, while those, like myself, who had none were obliged to look out for themselves. It was a genuine case of "root hog or die" with no place to "root"

10, A little warmer, Rebels say that Sherman and staff have been captured. Night cold and cheerless. Drew a board over me and tried to sleep.

11, Warm and pleasant. Night cold. Sat up all night.

12, Warm and sunshining brightly. Six federal officers are brought in. Night a little warmer.

13 Pleasant. Tunnel discovered. Federal prisoner shackeled with ball and chain on suspicion of tunneling

14, Report in circulation that Jeff. Davis has issued a proclamation declaring his intention of placing negroes in the ranks. Weather fair

15, Pleasant. Six or seven paroled officers brought in for refusing to sign parole not to escape in going to Charleston, S. C.

16, Two prisoners brought in. Night cool.

17, Cool morning. At 4 o'clock A.M. left Macon and took the cars for Camp Lawton, five miles from Millen Ga. 12 or 14 prisoners cut a hole through the end of the car I was in and escaped by jumping off. As the train was running at a high rate of speed it is very likely they were killed, but "give me liberty or give me death" was their motto.

18, Taken to the stockade. While awaiting outside several of our boys slipped away by having on rebel clothes. A "confed", with a pail on his arm, on his way to the spring, stopped to gaze at the "yanks" for a few moments. He sat his pail down and one of our boys in reb. clothes stepped out of ranks, picked it up and struck out for - liberty. I find sergt. John B. Chaney ${ }^{1}$ of my company (H.) and Chas. Nelson ${ }^{2}$ and Saml.

${ }^{1}$ Sgt. John B. Chaney, a native of Indiana, was wounded and token prisoner Nov. 27, 1863 at Ringgold, Ga. He was mustered out April 24,1865 at Louisvillo, Ky.

${ }^{2}$ Corp. Charles Nelson of Bedford, Iowa, was taken prisoner Aug. 11, 1863 at Black River, Miss. He remained a prisoner until the end of the war. 
Hutton $^{3}$ of " $\mathrm{K}$ " and am kindly invited to quarter with them Drew one days rations, a little meal, Beans and fresh beef. 19, Day pleasant. Early roll call. 20, Weather pleasant. Am beginning to realize the miseries of prison life.

21, Rebel guards are brought in to search for axes, spades, etc. belonging to the prisoners, but the boys are too smart for them-every thing is burried [sic] in time.

22, Cool. Night cold and frosty.

23 , Oh! such a horrid spectacle as the camp presented this morning! Dead and dying could be seen on every hand, having perished of cold during the night. It was an awful sight, more like a hard fought battle field with the dead and wounded where they have fallen, than anything else I ever saw.

24, Pleasant morning. Organized into a "division" and moved to North side of Stockade to ground assigned us.

Note: A division was composed of 500 men with one of our sergts. in charge. Each 100 also had a non-commission officer in charge, so had each mess of 25 . We had no tents nor shelter of any kind and none was furnished. We received no cooking utensils.

25, Considerable stir in camp. The names of foreign born soldiers being taken down and marked. What does it mean? We cannot tell unless it is to allow them to enlist in the rebel service. I think they are too loyal for that.

26, Cool and breezy.

27, It is rumored that the rebels have recaptured Atlanta

28, Cool and windy. Foreigners are taken outside and a proposition made to them to enlist in the rebel service. About three hundred stay out - the rest come back.

29, A call made for carpenters to work outside on parole of honor. Day warm and pleasant. Two of the "foreigners" brought in, having run away and been caught We learn that 60 or 70 , in all, ran off.

30 , Warm and pleasant. Went outside with wood squad to

${ }^{3}$ Samuel Hutton, a resident of Page County, Iowa, was taken prisoner Aug. 12, 1863 at Black River, Miss. He remained a prisoner until the end of the war. 
gather wood for camp. More talk of an exchange of prisoners at Savannah.

31, Two months since captured at Jonesboro. Day warm and pleasant

Nov. 1, About 1000 prisoners brought in from Andersonville, Amongst them, Sergt. Fees ${ }^{4}$ and J. Z. Darwin ${ }^{5}$ of my company.

2, Day appointed for fasting, and prayer, throughout the "so called" Southern Confederacy. Cold and rainy. Between 600 and 700 prisoners brought in from Cahawba Ala.

3, Cold and rainy. About 1000 prisoners brought in from Andersonville.

4, Cold and disagreeable. More prisoners taken out to enter the rebel service. More prisoners brought in

5, Warmer. More prisoners brought in, among them John Sturman $^{6}$ of Company "F".

6. One man killed and another wounded by rebel guard.

7. Quite warm. Pretty reliable reports that an exchange of sick and wounded prisoners will take place in a few days.

8 , Some appearance of rain, otherwise pleasant. Had an election for president 4,644 votes polled. Lincoln's majority 934.

Note: The rebel officers were anxious that we hold an election, and provided us with blank paper and a couple of boxes. They seemed to believe that the prisoners' vote would foreshadow the vote of the North. A majority for [George B.] McClellan meant peace, or rather compromise, while a majority for Lincoln meant war. They promised extra rations of sweet potatoes, if McClellan received a majority of the votes cast; and how far this promise went towards influencing starving men in voting, will probably never be known.

${ }^{4}$ Sgt. Jacob W. Fees, a native of Indiana, was taken prisoner March 14, 1864 at Claysville, Ala. He was mustered out June 15, 1865.

${ }^{5}$ Joseph Z. Darwin was taken prisoner March 14, 1864 at Claysville, Ala. He was mustered out June 12, 1865.

${ }^{6}$ This is most probably John J. Sturman of Madison County, Iowa, although the Roster and Record of Iowa Soldiers does not indicate that he was ever taken prisoner. Sturman served from April 1861 to August of the same year; he re-enlisted Jan. 25, 1864 and was mustered out April 24, 1865 at Louisville, Ky. 
9, Looks quite like a summer day-a summer day on a battle field - so many dead are being borne past me, as I write. Have contracted a bad cold and am not well today.

10, Cloudy with rain. Feel better today. Afternoon fair but cool.

11, Forenoon cloudy with a little rain. Afternoon pleasant. Rebels call for more recruits among the prisoners. They get 150 or 200 . The sick are being examined and names taken. We think they will be exchanged in a few days

12, Frost on the ground this morning. A call for more recruits

13 Examination of sick continued. Quite a large number of prisoners pay the rebels $\$ 50$, and upwards to get their names on the list for exchange.

14 Pleasant. More names are taken down for the "ready cash". Drew sweet potatoes in place of meal.

15 , Sick, and wounded, and those who bought out, besides several small boys taken out for exchange. Sergt. Chaney goes with them. Some late captured prisoners brought in. They report a general exchange in progress.

16, Those taken out for exchange, brought back again, to be taken out on Friday

17, Pleasant. More sick to be examined to-morrow.

18, More sick examined. Was examined but did not "pass muster"- did not get my name taken down.

19, About 1,000 sick and convalescent taken out for exchange. Quite a large num[ber] of well ones buy themselves out, 30 paroled men from outside taken to Savannah for exchange. 20, Cloudy with rain.

21, At one oclock A.M. 2nd, 3rd, and 4th Divisions ordered to "fall in". "Fell in", with 3d div., passed outside stockade, and marched to depot where we were piled into hog cars. Drew a little beef and hard tack. Started at daylight for Savannah with high hopes of being exchanged. Reached Savannah at sundown. After dark exchanged cars and ran 15 or 20 miles in a southerly direction on the Gulf R.R. where the train stopped. Water on both sides of the track. It had rained all day and was quite cold. 
22, Cold and chilly. Something wrong with engine, which caused us to lay by, until 10 o'clock, A.M., when another engine from Savannah, backed us to McIntosh station, distant 31 miles from Savannah. Hopes of exchange have vanished, and another "bull pen" seems inevitable. About dark, got off the cars, and camped near R.R. ${ }^{\mathrm{d}}$ all night. Drew a pint of raw corn, and a little fresh beef, to each man. Night very cold.

23, Broke up camp, and got on the cars, about ten o'clock A.M. Reached Blackshear station at dark. Did not get anything to eat. Night very cold. Arriving late, we were not allowed any wood, and those prisoners who had reached camp in advance would not share with us what they had.

24, Drew a little hard bread-three small crackers to each man. Were moved about one mile from R.R. and camped in thick pine woods. Did not get anything more to eat. Prisoners begin to fell trees to build "Shebangs". Man knocked down by falling tree.

25, Drew some hard bread, beef and salt. One man killed, and one had an arm broken by falling tree. Orders to fall no more trees. Three men run guard line after dark, are fired at but escape

26, 1000 men sign parole and are taken away. A fair prospect for the rest of us being paroled. The three escaped prisoners brought back.

27, A general rush to get out. Sergts. of hundreds draw lots to see who goes today. 1,000 go out but are not paroled-some say because it is Sunday Sergts. draw again and our hundred will go next time. The 1000 do not go away but come into camp again.

28, No prisoners go away to-day. Report says transportation is all taken up to carry troops to the front. Have some doubts about the parole being a bona fide one. Drew two days rations; one of meal and beef, the other of molasses and corn bread

29, Camp reorganized and hundreds filled up. I "flank" into another hundred so as to draw double rations. The rebels find they have 579 men less than had been drawing rations 1000 go out to be paroled. 
30, Three months a prisoner. Prisoner shot and mortally wounded by rebel guard. Another badly injured by falling tree 1000 expected to go away tomorrow.

Note. The shooting of this prisoner was a most cowardly and brutal act. At Blackshear there was no stockade-only a guard line around the prisoners. Two stakes, to represent a gate, had been driven in the ground on one side [of] the camp and prisoners, in going out and in, for wood, and water, were obliged to pass between these stakes. This prisoner, only a boy, carelessly passed to one side and without a word of warning was shot.

Dec. 1, Got no rations. Camp made smaller. No prisoners leave to-day.

2, Two escaped prisoners brought in. They had been to the coast and saw one of our blockading vessels. The 1000 that went away last brought back-had been to Savannah. The first 1000 reported gone to Florence, S.C. Report also says that [Maj. Gen. Ambrose E.] Burnside has cut the Charleston and Savannah R.R.

3, Five prisoners run guard line last night and are fired at. One had an arm broken, the others made their escape. Clothing from the U.S. Sanitary Commission received and is issued to the most needy prisoners. More prisoners run away during the night.

4. It is reported that Sherman has captured Savannah. The clothing is issued. As far as it goes ten of the most needy, in every hundred, get either a shirt or a blanket. During the night more prisoners escape. Some talk of leaving this place soon

5, 1000 go away. Report says they have gone to Andersonville Ga. or Cahaba [sic] Ala.

6, Sick taken out, and hundreds filled up. I "flank" again. We draw parts of three days rations

7, Rainy. A guard takes seven men out for wood, and brings back only three Rains during the night. More men run away.

8. Had a chill, with fever, and was quite sick all day. Some escaped prisoners brought in. Rebel guard accidentally shoots himself through the hand. More prisoners run away during the night. 
9, Rainy. Received marching orders. More prisoners run away during the night.

10, Left Blackshear at five o'clock A.M. on the cars. Rainy. Reached Thomasville [Ga.] at dark, then marched one mile, through mud and water and camped in the fine forest.

11, Cold and windy. Drew a little meal and salt

12 Cold. Some prisoners, captured near Savannah, brought in

13 Camp reorganized and hundreds filled up. I out-"flank" a rebel guard and get my name down in an extra "mess".

14, Myself and mess build us a "house". A little rain

15 , Pleasant. Some talk of leaving soon.

16, Another reorganization of camp. We are all marched outside of guard lines, forty or fifty rods, strongly guarded; and as soon as a hundred is made up and names taken it is marched back. "Flanking" is completely ended for the present.

17, Drew hard bread. Talk of leaving in a few days. Savannah reported captured with 7000 prisoners.

18, Will probably march to-morrow.

19, Left Thomasville early in the morning en route for Albany Ga. Marched ten miles.

20, Marched at an early hour-went 18 miles. Country poor and thinly settled on the road. Women, girls and dogs, very numerous all the way. Couldn't imagine where they all lived. Rainy night. No shelter.

21, Marched early. Roads muddy and full of swamps. Marched 16 miles.

22, Marched at daylight. Country more improved. Went about 16 miles and camped on Flint river, three miles from Albany. 1000 leave for Andersonville.

23, Marched two miles and camped on banks of Flint river, one mile from town. 1000 leave for Andersonville

24, Left camp at 4 o'clock P.M. and marched to Albany where we were crowded into freight cars and remained there all night. The car that I was in contained 113 men and all the other cars were more or less crowded. The cars were not seated. Ours was a slat-work car and I got a "johny" to pass a plank from the outside, through the slats, overhead. I, and another comrade, then occupied it and got some sleep. 
25, Today is Christmas, and a cold, rainy day. Cars started for Andersonville ${ }^{7}$ at five o'clock A.M. where we arrived about noon. After being organized by Capt. Wirz ${ }^{8}$ were put in stockade. At night two or three men got into a hole in the ground to shelter themselves from the storm and were killed by the ground caving in upon them.

26, The ballance [sic] of the prisoners (400) came in from Albany. Draw pint of cooked peas, three square inches of corn bread and about two ounces cooked beef-not enough for one meal.

27, Talk of leaving soon. Rumors of Jeff Davis' death. Rains at night

28 Draw very small rations. Night cold and windy.

29, Cold. Get but little wood or rations. Some talk of building barracks.

30, Cold. Rain at night.

31, Four months a prisoner, and the last day of the year. The year 1864, one of the most eventful of my life, has just expired. Last January, at Woodville, Ala., the 4th Iowa Infantry regiment reenlisted for three years or during the war. On the 26, of Feb. the regiment left Woodville en route for home on a furlough for thirty days. Language cannot describe the joy that filled each heart at the prospect of so soon meeting the loved ones at home, of hearing their warm welcome, and of being permitted to mingle once more in the social circles from which we had torn ourselves to enter the service of our country.

But the time passed swiftly away and soon we were on the battlefield again. During the summer the battles of Resaca, Dallas, Kenesaw Mountain, Atlanta and Jonesboro were fought and many a brave boy fell on those hotly contested battlefields. Jan. 1, 1865, Fair and bright. Get smaller rations than usual.

2, Fair. Hood reported falling back to Georgia and [George H.] Thomas in pursuit.

${ }^{7}$ Andersonville (or Camp Sumter) was the worst of Confederate prisons. Between 49,000 and 52,000 prisoners were confined within its walls during the Civil War; of this number about 25 per cent died.

${ }^{8}$ Capt. Henry Wirz, the superintendent of Andersonville, later became the first soldier sentenced to die for atrocities committed against prisoners-of-war. He was hanged Nov. 10, 1865. 
3, Cool and rainy. We draw some beef paunches and lights. Rations very small.

4, "Dead line" is found to have been torn down last night, by some one, to add to their scanty supply of wood and rebels threaten to stop our rations until the offending person is found. For eight rations a prisoner volunteers to take the blame upon himself. He is taken outside and placed in the stocks. Note, The "dead line" was a light railing, three feet high, placed fifteen feet from the stockade. The rebel guards had orders to fire upon any man who placed his hand upon the rail or touched it in any way

5, Pleasant. More paunches issued.

6, Chilly. Rain at night.

7, Pleasant. Two of my mess get out after pine boughs for bedding.

8, Two prisoners brought in-lately captured near Savannah. They report Sherman's army on its way to Charleston, S.C.

9, Cloudy. Afternoon rainy and rainy all night

10, Report in circulation, that an exchange of prisoners has been agreed upon and that we will soon be exchanged.

11, Report says a rebel captain said we would be exchanged next week.

12, Pleasant. Night cold and frosty.

13, Warm and pleasant. Favorable exchange rumors in circulation.

14, Cloudy morning. Day pleasant.

15 , Report says we are to leave on the $22 \mathrm{nd}$, for exchange.

16, Prison police disbanded. Sergts. of Divisions to act as police.

Note-The police was composed of federal prisoners and their duty was to preserve order both night and day. They received larger rations than the rest of the prisoners.

17, Nine prisoners who made their escape from Thomasville brought in.

18, Pleasant. Got out after wood.

19, Rained all day. A new police force organized

20, Rainy day. Rain all night.

21 , Rebel recruting officer comes into the prison to get recruits from among the prisoners. 
22, Rainy. Rebel officers in again recruiting. Quite a large number of prisoners expected to volunteer.

23 , Recruiting officers come in and take out about 40 recruits. 500 prisoners come in from Meridian, Miss.

24, Divisions filled up.

25 , Cold and chilly day.

26 Cold raw winds.

27, A little more pleasant. Some exchange rumors in circulation in camp.

28, Pretty cold. Lay nearly all day in my "tent".

29, A little warmer. Some peace rumors in circulation.

30 , Pleasant. Rebel papers say commissioners have gone to Washington to try to arrange terms for peace; That Sherman is marching to join Grant and that Thomas is marching upon Atlanta.

31, Five months a prisoner. Warm and pleasant.

Feb. 1, 400 or 500 prisoners brought in from Meridian, Miss. Richmond, Va., prisoners reported exchanged for.

2, A sutler store ${ }^{9}$ being built in camp. Report says the Florence, S.C., prisoners are coming here.

3 , Cloudy and rainy.

4, Pleasant. Rebel papers say a general exchange of prisoners is expected to take place soon.

5 Cold and disagreeable.

6, Rainy. Some prisoners, lately captured in Florida brought in. 7 , Forenoon cloudy with rainy, afternoon cold.

8 , It is reported that an exchange of prisoners will begin on the 18th inst. All prisoners, who have axes, ordered to report at the gate to go out to chop. All axes are taken from them on the plea that a plan had been formed to chop stockade down. Thus through treachery they got the axes.

Capt. Wirz comes inside. "More corn bread" is yelled at him by some one for which he threatens to stop our rations until the man is brought out.

Feb. 9, Cold. I get out for wood.

10, Rebel papers say Sherman captured Branchville.

11, Preaching in camp by Southern preacher.

${ }^{9} \mathrm{~A}$ sutler store sold to the troops provisions, liquors, etc. 
12 , Sergts. get up a petition to draw raw rations.

13, Wood-squad goes out, are searched and sent in again. The reason is, Wirz got wind that prisoners were going to make a break. Paroled men sent in. We begin to get raw rations.

14, Rainy. Lay abed all day.

15, Pleasant. Paroled men come in from Thomasville, Ga. More favorable exchange rumors afloat.

16 , A beautiful day. A prisoner while after wood, is recaptured by the hounds and put in the stocks.

17, Warm but windy. Sherman reported captured. Eight or ten prisoners brought in from Macon.

18. About 700 prisoners brought in. The papers say a general exchange of prisoners, both white and colored, has been agreed upon.

19, Forenoon pleasant. Afternoon cloudy.

20, Warm and pleasant.

21, Pleasant.

22 , This is my 24 th birthday. The papers contain very favorable news, of a general exchange, and say Sherman has captured Columbia, [N.C.] and Charleston, [N.C.]

23, We draw cooking utensils. The papers repeat yesterdays news.

24, Cloudy and rainy.

25, Rains all day. Various reports in circulation about leaving soon.

26 , One year since the 4 th Iowa started home on veteran furlough. Warm and pleasant.

27, Forenoon pleasant. Afternoon rainy. Rebel recruiting officers in camp.

28, Six months a prisoner. About 200 prisoners go out and take the oath of allegiance. Papers contain very favorable news. Weather cloudy. Rainy night.

Mar. 1, Rainy and cloudy. Guards say we will march soon but do not know where.

2, The paper say the point of exchange is Aiken's landing on Tames river and that our flag of truce boat will run regularly between that place and Annapolis, Md. After dark 106 prisoners come in from Augusta, Ga. Among them one from the 25th, and one from the 31st Iowa. 
3, South Carolina prisoners reported captured by Sherman. Various conflicting rumors in circulation.

4, Report in circulation that the sick will leave to-morrow and the well will begin to leave on Monday.

5 , The papers contain very favorable news, and we expect soon to be exchanged.

6, A train load of exchanged rebel prisoners pass through.

7, Guard said 1000 would be taken from the hospital today. 60 or 70 officers confined here reported to have left for exchange. (did not). Papers contain very favorable news.

8 , Barrels are issued in which to make corn beer to counteract the effect of scurvy. No news today.

9, Rainy day and night. Papers say all packages have been stopped by order Col. Mulford, owing to immediate exchange of all prisoners south.

10, Forenoon cold. Capt. Wirz sent in an order to the effect there was no foundation for the exchange rumors. Half an hour afterwards rebel recruiting officer comes in. Prisoners cut the buttons off the rear of his coat.

Note-Buttons were legal tender with the rebel soldiers, and would purchase meal, beans, etc. etc., and very few old prisoners but what had dispersed of their buttons.

11, Pleasant. Talk of leaving soon.

12, Capt. Wirz sends in word that all of the prisoners will be exchanged inside of two weeks, Crandall ${ }^{10}$ and Davis ${ }^{11}$ of Co. F. who are outside on parole of honor, sent in some beef, peas and meal, for $\mathrm{Z}$ and Sam Hutton.

13, Report in circulation that a point of exchange could not be agreed upon, in consequence of which the exchange has been postponed two months.

14, Talk of 1000 leaving to-morrow. Rainy night.

15, Rainy afternoon. Rebel officers come in and say we will be exchanged in one or two weeks.

16, Rainy forenoon-afternoon, cool and windy.

17, Saint Patricks day. Pleasant.

${ }^{10}$ Sgt. Wilford W. Crandall of Winterset, Iowa, was taken prisoner March 14, 1864 at Claysville, Ala. He was mustered out May 20, 1865.

${ }^{11}$ George B. Davis of Winterset, Iowa, was taken prisoner March

14, 1864 at Claysville, Ala. He was mustered out April 25, 1865. 
18, 1000 sick and well, including 45 or 50 officers taken out to be exchanged.

19, Quite a large number of men taken out to work on parole of honor.

20, More men taken out to work. Two trains with prisoners expected to leave to-morrow. Met with my cousin Henry Stoll of Co. G. 105th Ohio infantry who I had not seen for 17 years. He had been captured near Savannah, Ga.

21. Rained nearly all day. No news.

22, Reports, both good and bad incirculation. A few prisoners pay ten dollars to the rebels to have their names taken for the next load.

23 , Orders come in to have the prisoners ready to start immediately for exchange at Vicksburg, [Miss.]

24, Capt. Wirz says he has received a dispatch from Vicksburg, concerning the exchange, and two trains are expected to arrive in the morning. A train load leaves for exchange. About 250 paid to get out.

25,40 or 50 more pay to get out. Another load went away for exchange.

26,200 or 300 pay to get out. Another load went away for exchange about dark.

27, More men buy out with blankets, money, rings, buttons, etc. etc. A load goes out at noon, train does not come and they are brought in again.

28 , Rainy morning. A very dull day.

29, Our forces reported on raid within 75 miles of Montgomery, Ala. Rainy evening. Paroled men ordered to be ready to leave at any time after three o'clock, P.M.

30, The Col. commanding the first informed us that we would be exchanged at Jacksonville, Fla., to start as soon as transportation could be procured.

31, Seven months a prisoner. Forenoon quite chilly, afternoon more pleasant.

April 1, Capt. Wirz is reported gone to Macon to procure transportation.

2, Capt. Wirz comes in and says 600 will be paroled tomorrow —all to be gone by next Thursday night. About 2,200 prisoners still in Andersonville. 
3, 600 prisoners paroled-to leave tomorrow.

4, 1,100 prisoners leave for Jacksonville amongst them 30 or 40 negroes, 1100 more paroled, besides 40 officers and men just come from Macon.

5, I am paroled with the rest of the prisoners. 1,100 leave for Jacksonville. 5,000 prisoners reported on their way here.

6, Left Andersonville for exchange. Went to Albany on the cars. Camped near town.

7, Lay in camp all day. Visited by ladies from town. Some of the boys run guard line and go into the country foraging and are brought back by an old farmer and a double barrel shot gun. We are allowed to go bathing in the river.

8, Still in camp. Several ladies visit camp.

9, Still in camp. Ladies and gentlemen visit camp. Drew three days rations. Will probably leave tomorrow.

10, Still in camp. A great many reports in circulation, that we will go back to Vicksburg or Mobile, [Ala.]

11, Started at daylight for Andersonville and were put in stockade. The Col. commanding post caused a written notice to be posted up in the prison, pledging his honor that we would all be out by the 25th of the month, and satisfies us that he tells the truth.

12, Another load of prisoners come back, having gone fifteen miles beyond Albany.

13. Another load comes back having gone as far as Thomasville.

14, Guard say we will begin to go away next Monday. Reports in circulation that we will get separate paroles

15 , Some runaway prisoners brought in.

16, Report in camp that we are to be sent to Macon, Mobile reported in our possession.

Note-I believe that arrangements had been made with our authorities for our exchange at Jacksonville, Fla., but as our cavalry were on a raid, through Florida at the time, they wisely concluded to return us to the old "bull pen".

17, The masonic fraternity receive boxes of clothing provisions etc. Andersonville is evacuated for fear of a raid. The prisoners 
are started for Macon on three freight trains. The two first loads go through to Macon, the other within 18 miles of there. 18, We all turn back and run direct to Albany.

19, Four days rations issued. Are to start for our lines tomorrow morning.

20, Left camp before daylight-marched till after darkmarched 33 miles.

21, Left camp after sunrise. Marched 18 miles.

22, Marched 14 miles, and reached Thomasville about 5 o'clock, P.M. Boarded the cars at 11 o'clock P.M. and started for Jacksonville, Fla.

23 , On the cars all day. It is reported that three or four have fallen off the cars and are killed. Lay by all night within a few miles of Live Oak, Fla.

24, About noon reached Lake City, Fla. Ran about five miles below town and Camped.

25, The Georgia militia are relieved by the first Florida Reserves. About 200 prisoners are paroled.

26 , The paroles are all signed. Some talk of getting separate paroles if our authorities refuse to receive us. Reports in circulation that Lincoln has been assassinated, that an armistice has been agreed upon, and that Lee has surrendered with 7000 of his men.

27 , We draw two days rations - are to leave tomorrow, so says the rebel quartermaster.

28, We leave camp early, and run to Baldwin, on the cars. Are escorted beyond their outpost and turned loose, and reach our lines at Jacksonville at sundown after having been a prisoner of war seven months and twenty eight days.

Here ends my diary of prison life and may I never have occasion to write another.

Ames was mustered out June 26, 1865. He then returned to Afton where he purchased farm land. In November of the same year he married Sarah E. Ball; they were the parents of nine children. Amos Ames continued farming until his death, Feb. 13, 1913. 
Copyright of Annals of Iowa is the property of State of Iowa, by \& through the State Historical Society of Iowa and its content may not be copied or emailed to multiple sites or posted to a listserv without the copyright holder's express written permission. However, users may print, download, or email articles for individual use. 